\title{
Efeito do tratamento com dimetil fumarato na evolução clínica da encefalomielite
}

\section{experimental autoimune.}

\author{
Breno B. Ferrari*, Veronica A. P.G Silva, Leonilda M. B. Santos. \\ Laboratório de Neuroimunologia, Instituto de Biologia, UNICAMP, Departamento de Neurologia, HC-UNICAMP. \\ Centro de Atendimento e Tratamento de Esclerose Múltipla (CATEM), Santa Casa, São Paulo.
}

\section{Resumo}

O dimetil fumarato (TECFIDERA) é um fármaco de uso oral para o tratamento da Esclerose múltipla. Trata-se de um fármaco que há algum tempo é usado para o tratamento da psoriases, no entanto pouco se sabe sobre o mecanismo de ação. No presente estudo, verificamos o efeito do DMF na evolução da encefalomielite experimental autoimune e sobre as subpopulações de linfócitos T. Os resultados mostram que o tratamento reduz a gravidade da EAE e a redução da doença foi acompanhada de aumento de linfócitos T reguladores Foxp3+ tanto no baço como nas placas de Peyer dos animais tratados.

\section{Palavras-chave:}

Desmielinização; esclerose múltipla; dimetil fumarato.

\section{Introdução}

\section{A esclerose múltipla (EM) é uma doença} autoimune do sistema nervoso central (SNC) que pode levar à incapacidade física em adultos jovens. A encefalomielite experimental autoimune (EAE) é o modelo experimental de estudo da EM. O dimetil fumarato é um fármaco aprovado para o tratamento da $E M$, no entanto pouco se conhece sobre o mecanismo de ação desse produto. O presente estudo tem por objetivo estudar o efeito do tratamento com o dimetil fumarato na evolução da EAE.

\section{Resultados e Discussão}

Camundongos C57bl/6 foram imunizados com o peptídeo de MOG35-55 e a doença foi avaliada diariamente. Os subtipos de linfócitos foram identificados por citometria de fluxo.

\section{Figura 1A}

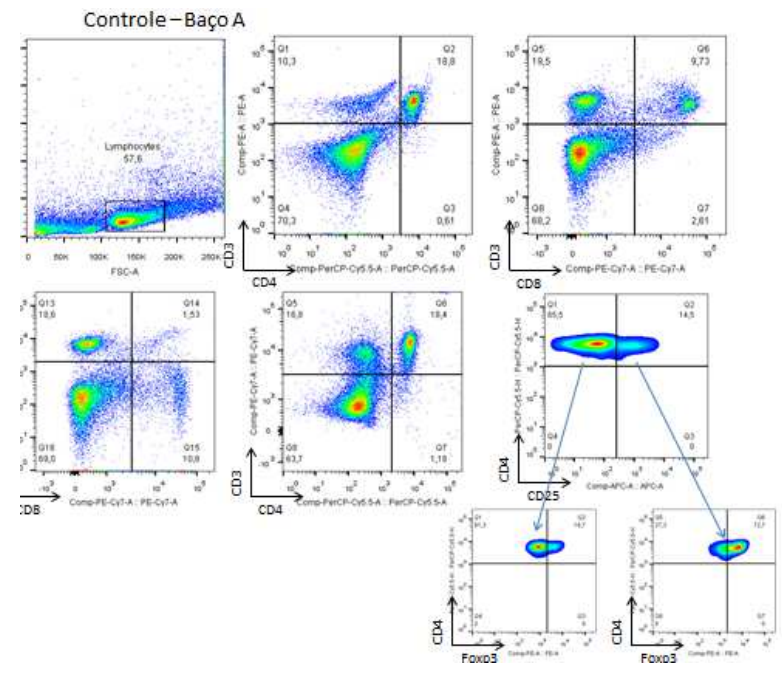

Figura 1: Na figura $1 \mathrm{~A}$ temos a estratégia de análise em citometria de fluxo.

\section{Figura 1B}
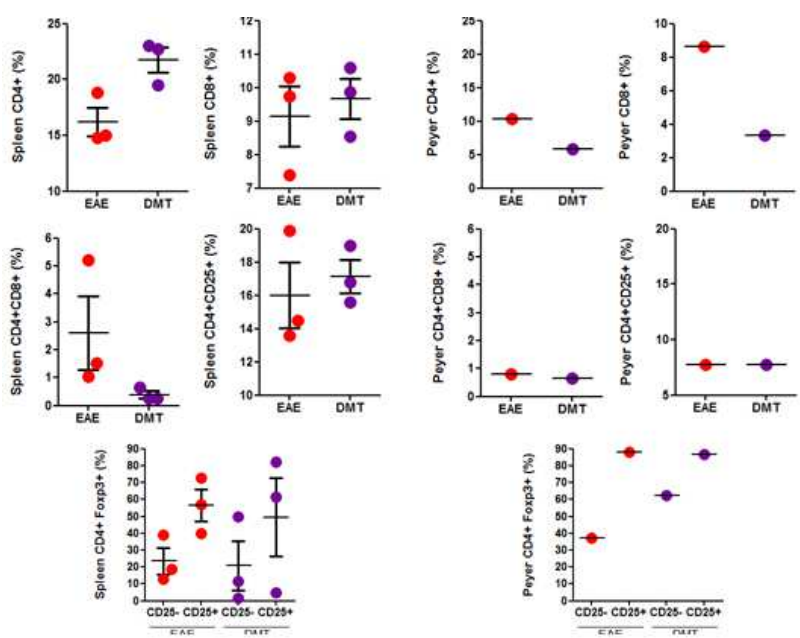

Figura 1B: Os resultados da quantificação de linfócitos CD4, CD8 e CD4 CD25 foxp3 no baço e placas de Peyer de camundongos com EAE e com EAE tratados com DMF. EAE vermelho EAE+DMF lilás.

Os resultados obtidos mostram que o tratamento com o DMF reduz de forma significativa a gravidade da EAE. A redução da doença é acompanhada de redução dos linfócitos T CD8 nas placas de Peyer e aumento dos linfócitos T CD4 CD25 Foxp3 positivos tanto no baço, como nas placas de Peyer. As células T reguladoras são marcadas pelas moléculas CD25 e o fator de transcrição Foxp3. Essas células reduzem a resposta imune.

\section{Conclusão}

Nesse estudo foi observado aumento dessa população celular o que explica, pelo menos em parte, a redução significativa da EAE.

* Chen H, Assmann JC, Krenz A, Rahman M, et al. Hydroxycarboxylic acid receptor 2 mediates dimethyl fumarate's protective effect in EAE. J Clin Invest. 2014; 124: 2188-2192.

* Kappos L, Gold R, Miller DH, Macmanus DG, et al. BG-12 Phase IIb Study Investigators. Efficacy and safety of oral fumarate in patients with relapsingremitting multiple sclerosis: a multicentre, randomised, double-blind, placebocontrolled phase IIb study. Lancet. 2008; 372: 1463-1472. 